\title{
Article \\ Influence of Solvent System on the Electrochemical Properties of a closo-Borate Electrolyte Salt
}

\author{
Matthew Green, Hovnan Simonyan, Katty Kaydanik and Joseph A. Teprovich, Jr. *(1)
}

check for updates

Citation: Green, M.; Simonyan, H.; Kaydanik, K.; Teprovich, J.A., Jr. Influence of Solvent System on the Electrochemical Properties of a closo-Borate Electrolyte Salt. Appl. Sci. 2022, 12, 2273. https://doi.org/ 10.3390/app12052273

Academic Editor: Oriele Palumbo

Received: 8 January 2022

Accepted: 15 February 2022

Published: 22 February 2022

Publisher's Note: MDPI stays neutral with regard to jurisdictional claims in published maps and institutional affiliations.

Copyright: (C) 2022 by the authors. Licensee MDPI, Basel, Switzerland. This article is an open access article distributed under the terms and conditions of the Creative Commons Attribution (CC BY) license (https:// creativecommons.org/licenses/by/ $4.0 /)$.

\author{
Department of Chemistry \& Biochemistry, California State University Northridge, Northridge, CA 91330, USA; \\ matthew.green.50@my.csun.edu (M.G.); hovnan.simonyan.134@my.csun.edu (H.S.); \\ katty.kaydanik.357@my.csun.edu (K.K.) \\ * Correspondence: joseph.teprovich@csun.edu
}

\begin{abstract}
In this study, the use of a closo-borate salt as an electrolyte for lithium-ion batteries (LIB) was evaluated in a series of solvent systems. The lithium closo-borate salts are a unique class of halogen-free salts that have the potential to offer some advantages over the halogenated salts currently employed in commercially available LIB due to their chemical and thermal stability. To evaluate this concept, three different solvent systems were prepared with a lithium closo-borate salt to make a liquid electrolyte (propylene carbonate, ethylene carbonate:dimethyl carbonate, and 1-Butyl-3methylimidazolium bis(trifluoromethylsulfonyl)imide). The closo-borate containing electrolytes were then compared by utilizing them with three different electroactive electrode materials. Their cycle stability and performance at various charge/discharge rates was also investigated. Based on the symmetrical cell and galvanostaic cycling studies it was determined that the carbonate based liquid electrolytes performed better than the ionic liquid electrolyte. This work demonstrates that halogen free closo-borate salts are interesting candidates and worthy of further investigation as lithium salts for LIB.
\end{abstract}

Keywords: closo-borate; liquid electrolyte; lithium; FTIR; galvanostatic cycling; lithium-ion battery

\section{Introduction}

Lithium-ion batteries (LIB) have emerged as ubiquitous components of personal consumer electronics, electric vehicles, and grid storage owing to their high energy density. Although significant advances have been made to fine-tune and enhance the properties of cathode and anode materials, the electrolyte salt $\left(\mathrm{LiPF}_{6}\right)$ used in many these systems has remained nearly constant since the rechargeable LIB was released by Sony in the early 1990s [1]. $\mathrm{LiPF}_{6}$ has a low ionic conductivity in the solid-state so it must be dissolved in a nonaqueous solvent to facilitate its dissociation and produce mobile $\mathrm{Li}^{+}$in solution to facilitate charging and discharging. Manufacturers have developed a series of carbonate based solvent systems and additives to enhance cycle stability, ionic conductivity, thermal stability, and solid electrolyte interface (SEI) formation. However, the carbonates used are flammable and can act as a fuel source if there is a short circuit or thermal runaway in a battery. This has led to the investigation of ionic liquids as the solvent medium or additives for LIB to reduce or eliminate the flammable component of the electrolyte system [2].

The other common lithium salts utilized for this purpose include but are not limited to $\mathrm{LiAsF}_{6}, \mathrm{LiBF}_{6}$, and $\mathrm{LiClO}_{4}$. However, these other salts are typically only utilized in a laboratory setting and are not typically found in commercial LIB due to similar drawbacks among other issues. As the deployment of LIB increases, there is an ever-increasing need to consider safety and possible recycling issues associated with these and similar systems. This is attributed to the tendency of $\mathrm{PF}_{6}{ }^{-}$to undergo hydrolysis and form HF upon exposure to moisture or form reactive byproducts at elevated temperatures. The chemical stability and safety issues associated with current commercial electrolyte systems has gained 
international attention through incidents that occurred with the Boeing 787 Dreamliner, Tesla Model S, and Samsung Note 7.

The high chemical reactivity and low thermal stability of halogenated electrolytes has led to the search for halogen-free alternatives that offer similar or enhanced electrochemical performance, have low chemical reactivity, and are thermally stable. This has led to an interest in the lithium salts of anionic polyhydroborate clusters as possible candidates. Many of these large boron rich anion (LBRA) clusters are considered superhalogens because they have vertical displacement energies (VDE), the energy needed to remove an electron from the cluster, greater than that of the halogen group [3,4]. The metal salts containing LBRA have been extensively studied because they are often problematic intermediates or unwanted byproducts resulting from the dehydrogenation of metal borohydrides being investigated for solid-state hydrogen storage $[5,6]$. This has led to the discovery that highly mobile cationic and anion species are present in these materials via various methodologies.

It has been shown that a number of LBRA containing salts $\left(\mathrm{M}_{2} \mathrm{~B}_{12} \mathrm{H}_{12}, \mathrm{M}_{2} \mathrm{~B}_{11} \mathrm{H}_{11}\right.$, $\mathrm{M}_{2} \mathrm{~B}_{10} \mathrm{H}_{10}, \mathrm{MCB}_{11} \mathrm{H}_{12}, \mathrm{MCB}_{9} \mathrm{H}_{10}, \mathrm{MB}_{11} \mathrm{H}_{14}$, etc.) have cationic conductivities $>10^{-1} \mathrm{~S} / \mathrm{cm}$ in the solid state [7-23]. This behavior is attributed to the unique vibrational and rotational dynamics of the LBRA that can to occur on time scales faster than cation diffusion in the solid state [24-26]. A series of NMR, QENS, and MD calculations have demonstrated that the cation translational mobility is correlated with the reorientation rate of the LBRA consistent with a "paddle-wheel" mechanism $[10,25,27,28]$. This cation translational motion and anion reorientation rate can be tuned via temperature (phase transitions), cation vacancies, the type of atom attached to the boron cage (i.e., $\mathrm{H}, \mathrm{Cl}, \mathrm{F}, \mathrm{Br}$ ), and LBRA size $[7,12,13,29-33]$.

While there has been an extensive experimental and theoretical analysis of LBRA salts in the solid-state, there is limited understanding of how these materials behave and perform when used in a liquid electrolyte system. Some of the initial work investigating the use of lithium LBRA salts as non-aqueous electrolytes were initiated in the early 80 s by recent Nobel Laureate M. Stanley Whittingham and colleagues at Exxon [34-36]. They utilized the lithium salt of a chlorinated closo-borate $\left(\mathrm{Li}_{2} \mathrm{~B}_{10} \mathrm{Cl}_{10}\right)$. Since this initial work, there are only a few other reports using lithium closo-borate salts as either electrolytes or redox shuttles for overcharge protection in LIB [37-39]. In all of these prior studies, the lithium closo-borate was halogenated (typically fluorinated) to improve solubility. Additional MO calculations found that the dissociation energy of the first $\mathrm{Li}^{+}$from $\mathrm{Li}_{2} \mathrm{~B}_{12} \mathrm{~F}_{12}(126 \mathrm{kcal} / \mathrm{mol})$ is actually lower than the dissociation energy of $\mathrm{LiPF}_{6}(132 \mathrm{kcal} / \mathrm{mol})$ [40]. However, the dissociation of the second $\mathrm{Li}^{+}$from $\mathrm{Li}_{2} \mathrm{~B}_{12} \mathrm{~F}_{12}$ is significantly higher $(192 \mathrm{kcal} / \mathrm{mol})$. This is consistent with a dynamic equilibrium existing in solution with $\mathrm{Li}^{+}, \mathrm{LiB}_{12} \mathrm{~F}_{12}{ }^{-}$, and $\mathrm{B}_{12} \mathrm{~F}_{12}{ }^{-2}$ present in these electrolyte solutions.

LBRA, such as the closo-borates, do not readily undergo hydrolysis to produce acidic byproducts even when halogenated unlike the common anion $\left(\mathrm{PF}_{6}{ }^{-}\right)$utilized in current liquid electrolytes for LIB. In fact, the LBRA salts are often isolated as $\mathrm{M}_{\mathrm{n}} \mathrm{B}_{\mathrm{y}} \mathrm{X}_{\mathrm{z}}(\mathrm{M}=$ alkali or alkaline earth metal, $\mathrm{X}=\mathrm{H}, \mathrm{F}, \mathrm{Cl}, \mathrm{Br}, \mathrm{I}$ ) hydrates that are dehydrated under vacuum at elevated temperatures $\left(>200{ }^{\circ} \mathrm{C}\right)$ to obtain the anhydrous form [36]. Other alkali ( $\mathrm{Na}$, $\mathrm{K}, \mathrm{Cs}$ ) LBRA salts can be prepared from the acid form of the LBRA followed by cation exchange with an alkali hydroxide $[7,25]$. The excellent water and thermal stability were the impetus for investigating a halogen-free lithium closo-borate salt in common liquid electrolyte systems. Additionally, the halogenated version of the closo-borates requires the use of fluorine or chlorine gas in their synthesis which has inherent safety concerns and may reduce their access in certain research settings.

In this report we evaluate the electrochemical properties of a halogen-free closo-borate salt $\left(\mathrm{Li}_{2} \mathrm{~B}_{12} \mathrm{H}_{12}\right)$ in three different liquid solvents (propylene carbonate, ethylene carbonate:dimethyl carbonate, and 1-Butyl-3-methylimidazolium bis(trifluoromethylsulfonyl)imide). Symmetrical Li/Li cells were assembled and cycled to evaluate lithium stripping and plating of lithium at different current densities. Half cells were prepared with a lithium metal electrode and three different electroactive materials (titanium disulfide, lithium titanate, and 
perylenetetracarboxylic diimide) and cycled galvanostatically. The ionic conductivity and cycle performance of each liquid electrolyte is compared. FTIR is also utilized to investigate the interaction of the different solvent systems with the $\mathrm{Li}^{+}$and the $\mathrm{B}_{12} \mathrm{H}_{12}{ }^{-2}$.

\section{Materials and Methods}

\subsection{Chemicals}

All reagents were purchased from Fisher Scientific: propylene carbonate (PC), ethylene carbonate (EC), dimethyl carbonate (DMC), 1-Butyl-3-methylimidazolium bis(trifluoromethylsulfonyl)imide (BMIM-TFSI), titanium disulfide $\left(\mathrm{TiS}_{2}\right)$, lithium titanate $\left(\mathrm{Li}_{4} \mathrm{Ti}_{5} \mathrm{O}_{12}, \mathrm{LTO}\right)$, perylenetetracarboxylic diimide (PTCDI), decaborane, lithium borohydride $\left(\mathrm{LiBH}_{4}\right)$, and acetylene black $(\mathrm{AB})$.

\section{2. $\mathrm{Li}_{2} \mathrm{~B}_{12} \mathrm{H}_{12}$ Synthesis and Electrolyte Preparation}

Lithium dodecahydro-closo-dodecaborate, $\mathrm{Li}_{2} \mathrm{~B}_{12} \mathrm{H}_{12}$ (referred to as lithium closo-borate) was prepared in an argon filled glove box following a procedure previously described [41]. Briefly, stoichiometric ratios of lithium borohydride, $\mathrm{LiBH}_{4}$, and decaborane, $\mathrm{B}_{10} \mathrm{H}_{14}$, were measured into a stainless-steel ball mill and sealed. These materials were milled together using an MSK-SFM-Desk-Top High Speed Vibrating ball mill with $50 \mathrm{~g}$ of stainless-steel balls for $45 \mathrm{~min}$. The ball milling was completed in five-minute intervals. Each five minutes of ball milling was followed by a five-minute cool down period. After every ten minutes of ball milling, the material was brought back into the argon glovebox to be scraped down to encourage even milling. The resulting material was then measured into a stainless-steel Swagelok cell, sealed using copper gaskets, and annealed at $200^{\circ} \mathrm{C}$ for $18 \mathrm{~h}$ in a CF1100 Muffle Furnace. The Swagelok cell was then brought back into the argon glovebox and the annealed material was collected and ground using a mortar and pestle. The resulting $\mathrm{Li}_{2} \mathrm{~B}_{12} \mathrm{H}_{12}$ powder is light yellow in color.

The lithium closo-borate salt was used to prepare three $0.5 \mathrm{M}$ liquid electrolyte solutions with the following solvents: anhydrous propylene carbonate (PC), a 1:1 volume ratio of anhydrous ethylene carbonate (EC) and dimethyl carbonate (DMC), and anhydrous 1butyl-3-methylimidazolium bis(trifluoromethylsulfonyl)imide (BMIM-TFSI). $\mathrm{Li}_{2} \mathrm{~B}_{12} \mathrm{H}_{12}$ powder was very slowly incorporated into the anhydrous solvents with stirring and evenly dispersed via sonication to mitigate the formation of large agglomerations of material. A small portion of the closo-borate does precipitate over time, however, the solution is still opaque even when stored for months in a fridge at $5{ }^{\circ} \mathrm{C}$. The solid can be ready be redispersed with stir bar mixing before use.

\subsection{Anode/Cathode and Coin Cell Preparation}

Cathode materials were prepared on aluminum foil while anode materials were prepared on copper foil. A slurry was made using the following basic formula: active material (80 wt. \%), conductive carbon $(10 \mathrm{wt} . \%)$, and a binder $(10 \mathrm{wt} . \%)$. The active materials included LTO for anode preparations and $\mathrm{TiS}_{2}$ and PTCDI for cathode preparations. The conductive carbon utilized was acetylene black (AB) and the binder utilized was polyvinylidene fluoride (PVDF). The respective amounts of each powder were measured and homogenized using a mortar and pestle. A slurry was prepared by adding minimal amounts of n-methyl-2-pyrrolidone (NMP), with constant stirring. The prepared slurry was allowed to mix and pipetted onto its respective current collector and cast into a $11 \mu \mathrm{m}$-thin film using a micrometer doctor blade. The thin film was allowed to dry overnight at $80^{\circ} \mathrm{C}$. $\mathrm{TiS}_{2}$ active material slurries were sustained in an inert environment throughout preparation and cast in an argon glove bag. Once dry, $10 \mathrm{~mm}$ disks of the material were cut out using an individual hole punch. All capacities are reported with respect to the amount of active material in the anode or cathode (specific capacity).

Coin cells were prepared using CR 2032 cases. A $10 \mathrm{~mm}$ disk of Li foil was cut and placed at the center of the coin cell base. An $18 \mathrm{~mm}$ disk of glass fiber filter paper was utilized as a separator and was saturated using a small amount of the prepared liquid 
electrolyte solution. The anode or cathode disk was applied with the active material side down onto the filter paper separator. To ensure good contact of the electrodes with the electrolyte solution, a stainless-steel disk and spring were centered on top. The coin cell was closed using the cap and the cell was sealed using a Digital Pressure Controlled Electric Crimper. All electrochemical experiments were performed on BioLogic VMP3 multichannel potentiostat. Constant current cycling data was obtained using symmetrical coin cells constructed in a similar fashion, using Li foil disks with an area of $0.80436 \mathrm{~cm}^{2}$. Constant current cycling was performed at current densities of $0.25,0.5,0.75$, and $1 \mathrm{~mA} \mathrm{~cm}^{-2}$. Ionic conductivity of the liquid electrolyte solutions as a function of temperature was measured by electrochemical impedance spectroscopy (EIS) between two polished stainless steel blocking electrodes.

\section{Results}

\subsection{Electrochemical Properties}

The closo-borate salt was prepared by a solid state synthesis route previously reported [41]. This solid-state annealing process is known to yield a product that contains a mixture of closo-borates with the majority of the sample containing $\mathrm{Li}_{2} \mathrm{~B}_{12} \mathrm{H}_{12}(85 \mathrm{wt}$. \%), $\mathrm{Li}_{2} \mathrm{~B}_{10} \mathrm{H}_{10}$ (12 wt. \%), and a small fraction of other borates via ${ }^{11} \mathrm{~B}$ NMR [42]. Although, this process produces a mixture of closo-borates it has been well established in the literature that mixtures of closo-borates offer higher ionic conductivity in the solid-state than the two components individually [43]. Additionally, our investigation suggests that the need for a high purity closo-borate salt is not necessary for excellent electrochemical performance when paired with the electrode materials evaluated. Since $\mathrm{Li}_{2} \mathrm{~B}_{12} \mathrm{H}_{12}$ is the major component of the closo-borate salt mixture, it will be referred to as " $\mathrm{Li}_{2} \mathrm{~B}_{12} \mathrm{H}_{12}$ " herein.

The solubility of the $\mathrm{Li}_{2} \mathrm{~B}_{12} \mathrm{H}_{12}$ is relatively low and forms an opaque light-yellow suspension which resembles a "soggy sand" type of electrolyte for the three electrolyte systems tested. In a soggy sand type electrolyte, a solid-state inorganic filler (i.e., $\mathrm{TiO}_{2}$, $\mathrm{SiO}_{2}, \mathrm{Al}_{2} \mathrm{O}_{3}$ ) is dispersed in a liquid electrolyte containing a soluble lithium salt (i.e., $\mathrm{LiPF}_{6}$, $\mathrm{LiClO}_{4}, \mathrm{LiBF}_{4}$ ) [44-46]. In this type of electrolyte, it has been determined that the addition of the insoluble particles results in the formation of a solid-liquid interface that supports fast lithium-ion condition at this two-phase interface. This is attributed to the partial desolvation of the $\mathrm{Li}^{+}$leading to higher mobility at these boundary layers. In the electrolytes presented herein, a portion of the $\mathrm{Li}_{2} \mathrm{~B}_{12} \mathrm{H}_{12}$ is soluble, while another portion remains solid producing a solid-liquid interface that can facilitate fast ion transport along that boundary. This system is unique because the lithium salt and the solid-state filler $\left(\mathrm{Li}_{2} \mathrm{~B}_{12} \mathrm{H}_{12}\right)$ are both the same material.

The ionic conductivity of the electrolytes as a function of weight $\% \mathrm{Li}_{2} \mathrm{~B}_{12} \mathrm{H}_{12}$ was first evaluated with electrochemical impedance spectroscopy (EIS) in a modified Swagelok type cell (Figure 1a). A maximum conductivity was obtained with 5 weight $\% \mathrm{Li}_{2} \mathrm{~B}_{12} \mathrm{H}_{12}$ dispersed in the liquid electrolyte. The EC-DMC electrolyte shows the highest room temperature ionic conductivity $(4.3 \mathrm{mS} / \mathrm{cm})$ followed by PC electrolyte $(2.4 \mathrm{mS} / \mathrm{cm})$, and the BMIM-TFSI electrolyte $(1.1 \mathrm{mS} / \mathrm{cm})$ as shown in Figure $1 \mathrm{~b}$. As expected, the ionic conductivity increases as a function of temperature due to the added thermal energy in the system which helps to facilitate the dissociation of the salt, increasing the concentration of free $\mathrm{Li}^{+}$in solution. This also helps to reduce ion pairing leading to a higher concentration of charge carriers in solution and the observed higher ionic conductivity.

The observed trends for the ionic conductivity are likely attributed to a combination of the dielectric constant $(\varepsilon)$ of the solvent and its viscosity $(\eta)$. For PC, EC, DMC, and BMIM-TFSI the dielectric constants are $64.9,95.3,3.12$, and 14.0 , respectively, at $25^{\circ} \mathrm{C}$ (for $\mathrm{EC}$ the value is 89.8 in the liquid state at $40^{\circ} \mathrm{C}$; $\mathrm{EC} \mathrm{mp}=37^{\circ} \mathrm{C}$ ) $[47,48]$. The viscosity of $\mathrm{PC}, \mathrm{EC}, \mathrm{DMC}$, and BMIM-TFSI is $2.51,1.93,0.59$, and $61.14 \mathrm{cp}$, respectively, at $25^{\circ} \mathrm{C}$ (the value for $\mathrm{EC}$ is at $40^{\circ} \mathrm{C}$ ). The EC-DMC likely has the highest overall ionic conductivity because $\mathrm{EC}$ has the highest $\varepsilon$ while the DMC has the lowest $\eta$ values out of the series. The synergistic effect of the high $\varepsilon$ component (EC) and the low $\eta$ component (DMC) helps to 
dissolve the $\mathrm{Li}_{2} \mathrm{~B}_{12} \mathrm{H}_{12}$ and allows the least restriction to ion migration. PC has moderate $\varepsilon$ and $\eta$ values relative to the series leading to the intermediate ionic conductivity. The BMIM has an extremely high $\eta$ and a relatively low $\varepsilon$ value leading to the observed lower ionic conductivity for this electrolyte.

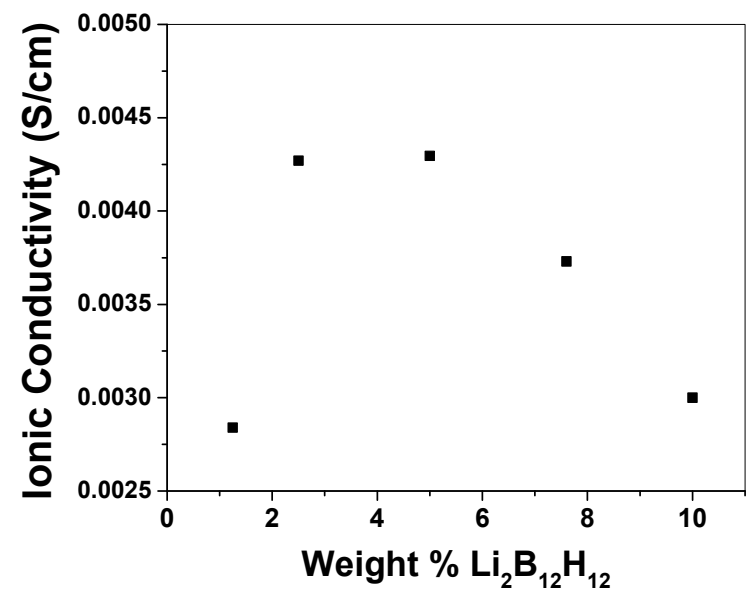

(a)

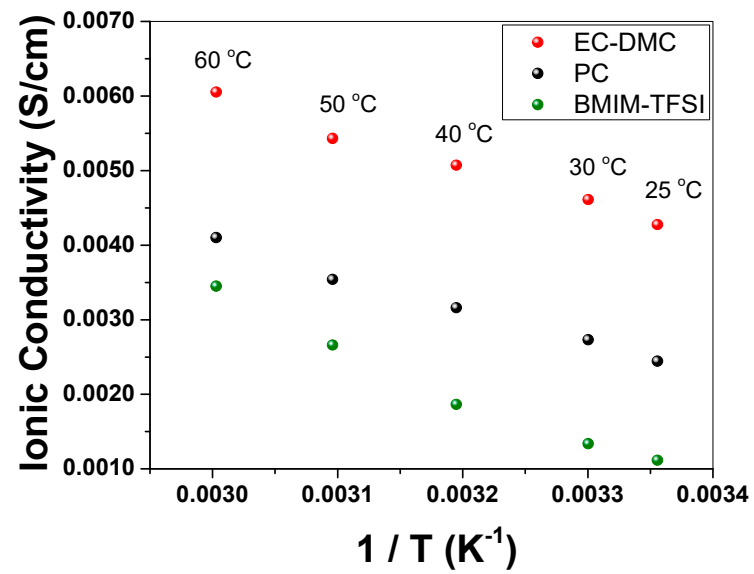

(b)

Figure 1. (a) Ionic conductivity in EC-DMC as a function of the weight $\%$ of $\mathrm{Li}_{2} \mathrm{~B}_{12} \mathrm{H}_{12}$ suspended in EC-DMC liquid. (b) Ionic conductivity as a function of temperature $\left(25\right.$ to $60{ }^{\circ} \mathrm{C}$ ) for the three different solvents containing $0.5 \mathrm{M} \mathrm{Li}_{2} \mathrm{~B}_{12} \mathrm{H}_{12}$.

To evaluate the stability and compatibility of the electrolytes with a lithium metal electrode, symmetrical cells (Li/electrolyte/Li) were assembled and cycled at different current densities (Figure 2). The EC-DMC electrolyte showed the lowest voltage hysteresis followed by PC and BMIM-TFSI which is consistent with the ionic conductivity measurements. In all three of the tested solvents, they showed compatibility with the metallic lithium electrodes and there was no obvious indication of shorting due to dendrite formation for the constant current cycling tested at the indicated current densities. However, it will be necessary to perform additional extended cycling and characterization of the 3 electrolyte systems to confirm this finding (Figure S1).

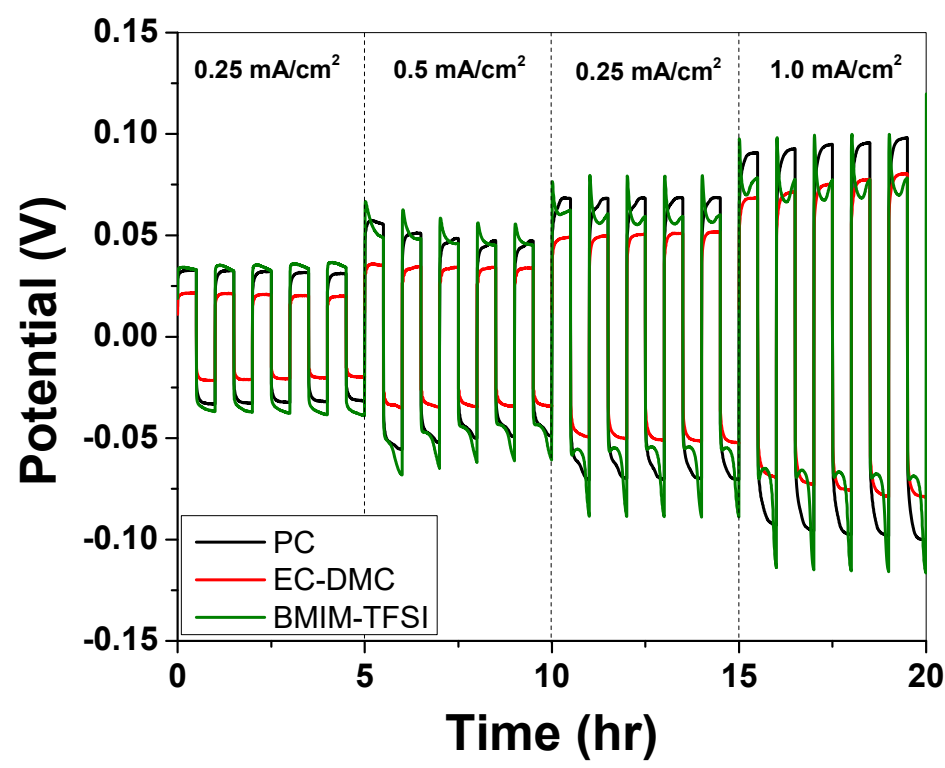

Figure 2. Constant current cycling using a symmetrical Li/electrolyte/Li cell cycled at different current densities with the three different electrolytes (PC, EC-DMC, and BMIM-TFSI) at $20^{\circ} \mathrm{C}$. 
Demonstrating compatibility with lithium metal anodes is essential for the development of new electrolyte systems and salts. The lithium metal anode has an extremely high theoretical specific gravimetric and volumetric capacities $\left(3860 \mathrm{mAh} / \mathrm{g}\right.$ and $\left.2061 \mathrm{mAh} / \mathrm{cm}^{3}\right)$ and the lowest negative electrochemical potential ( $-3.04 \mathrm{~V}$ vs. SHE) [49]. This would allow a significant enhancement in the gravimetric and volumetric capacity of commercial LIB if it replaced the graphite anode $\left(350 \mathrm{mAh} / \mathrm{g}\right.$ and $\left.760 \mathrm{mAh} / \mathrm{cm}^{3}\right)$. However, a major hurdle to overcome is the formation of lithium dendrites during the deposition of lithium from the cathode onto the lithium metal anode [50]. This requires the uniform deposition of lithium and minimization of "hotspots" that facilitate dendrite growth upon subsequent cycles. The evaluation of in-situ and ex-situ monitoring of the lithium deposition on the surface of the metallic lithium anode is currently under investigation for this series of electrolytes to confirm.

Figures $3-5$ show the galvanostatic cycling data for the three different solvent systems with $\mathrm{LTO}, \mathrm{TiS}_{2}$, and PTCDI respectively at the indicated cycling rates. For the anode LTO (Figure 3) the two carbonate-based electrolytes (PC and EC-DMC) display a relatively small loss in capacity as the cycle rate is increased from $0.1 \mathrm{C} \mathrm{(10} \mathrm{h} \mathrm{charge} \mathrm{or} \mathrm{discharge)} \mathrm{up} \mathrm{to} 10 \mathrm{C}$ (6 min charge or discharge). Both of these electrolytes show excellent and stable capacity retention up to 300 cycles at a rate of $2 \mathrm{C}$. The difference in capacity between the two carbonate electrolytes after 300 cycles is less than $4 \%$. The BMIM-TFSI electrolyte shows a significant capacity loss as the cycling rate is increased and has zero capacity at $10 \mathrm{C}$. The behavior of the cells prepared with the BMIM-TFSI also show very erratic and unstable cycling profile. The profile shown in Figure 3 is a typical example of the behavior observed for this electrolyte.

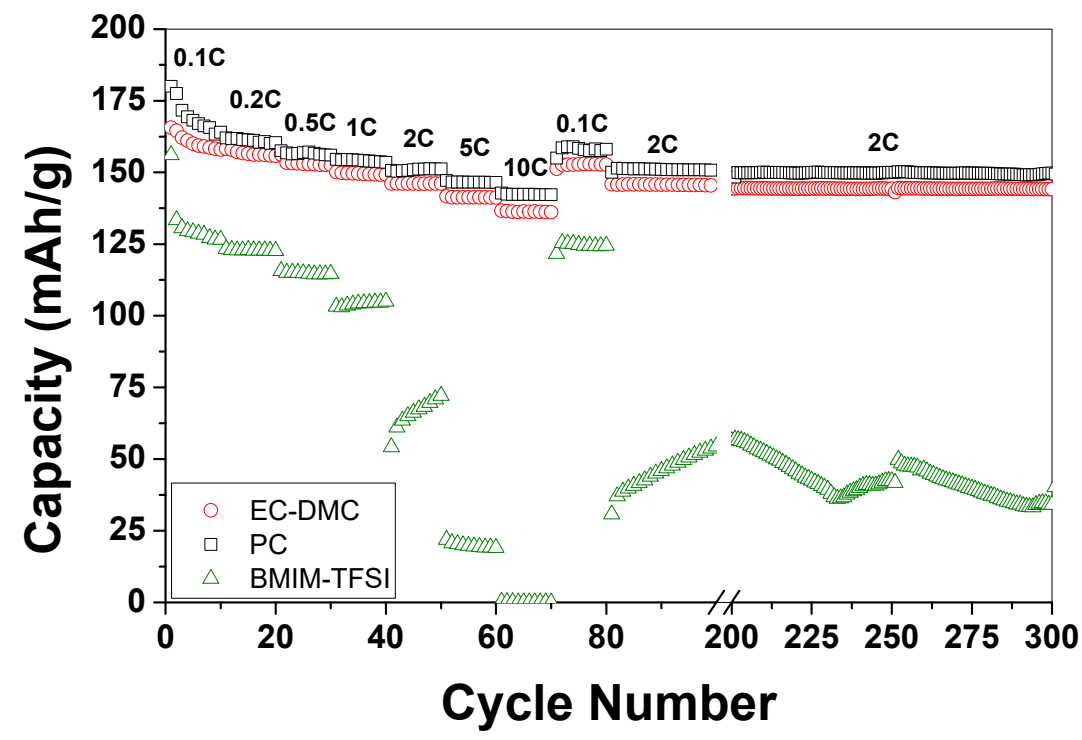

Figure 3. Comparison of the galvanostatic cycling performance of an LTO anode when paired with the three different electrolytes at the indicated cycling rates at $20^{\circ} \mathrm{C}$.

The cycle stability of the $\mathrm{TiS}_{2}$ cathode is shown in Figure 4 for the solvent systems. The EC-DMC electrolyte clearly showed a higher capacity retention over the PC electrolyte up to $5 \mathrm{C}$. However, both of the carbonate electrolytes do not show any capacity at the high cycling rate at $10 \mathrm{C}$. During extended cycling at $2 \mathrm{C}$ up to 300 cycles the EC-DMC electrolyte clearly outperforms the PC electrolyte by maintaining a $178 \mathrm{mAh} / \mathrm{g}$ capacity versus $154 \mathrm{mAh} / \mathrm{g}$. This extended cycling also suggests that the closo-borate salt with the lithium metal anode is relatively stable. The BMIM-TFSI showed a low capacity even at the lowest cycling rate $(112 \mathrm{mAh} / \mathrm{g})$ which dropped significantly as the cycling rate increased. It showed little to no capacity during the extended cycling study at $2 \mathrm{C}$. Figure S5 contains the full cycling study including the omitted points from Figures 3 and 4. 


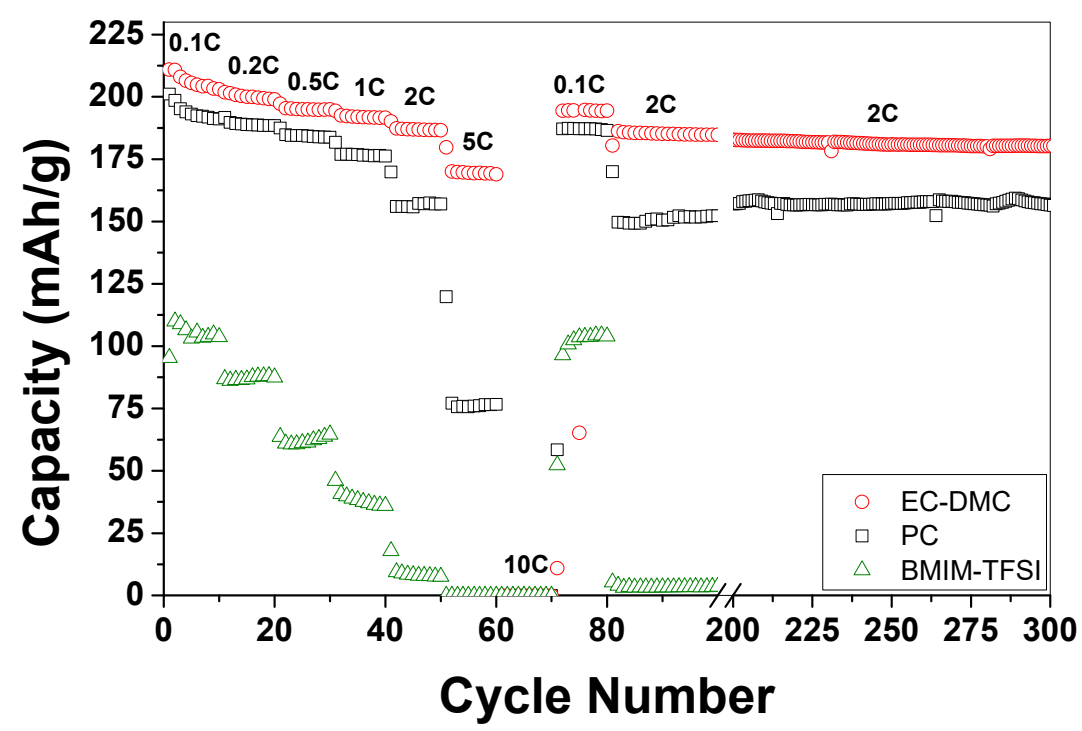

Figure 4. Comparison of the galvanostatic cycling performance of a $\mathrm{TiS}_{2}$ cathode when paired with the three different electrolytes at the indicated cycling rates at $20^{\circ} \mathrm{C}$.

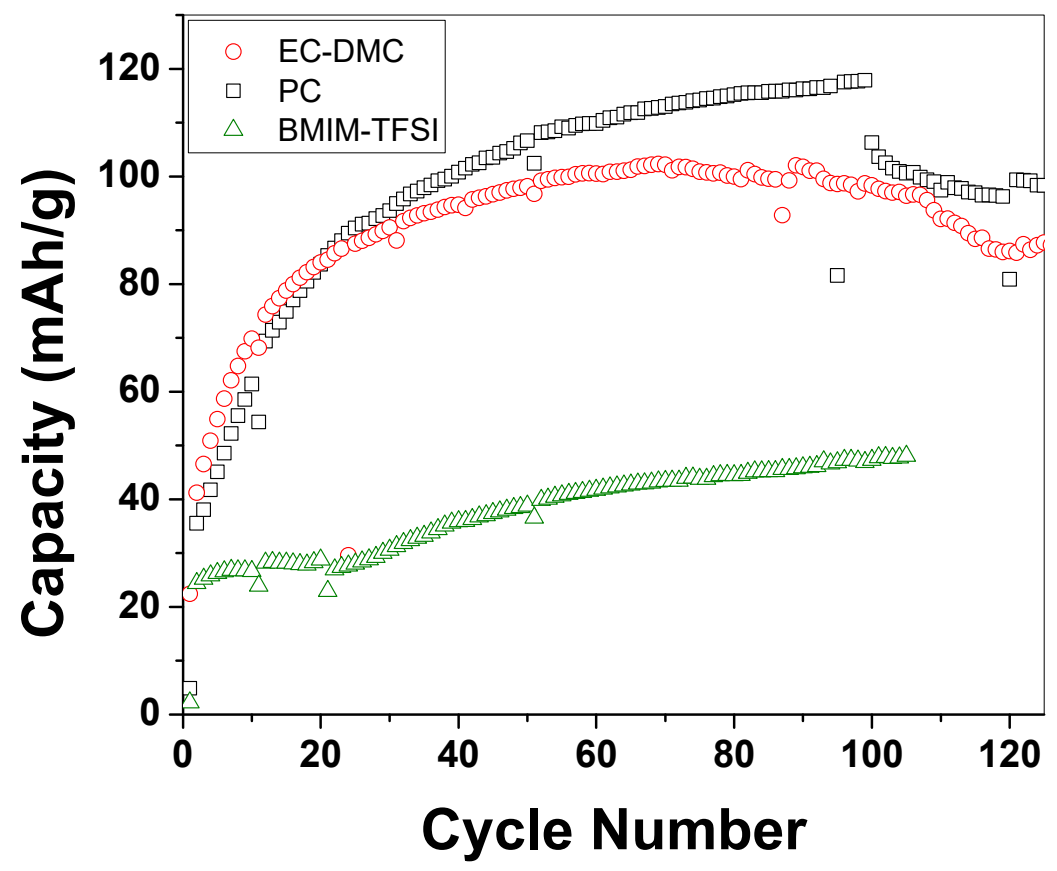

Figure 5. Comparison of the galvanostatic cycling performance of a PTCDI cathode when paired with the three different electrolytes at the same current density $(20 \mathrm{~mA} / \mathrm{g})$ at $20^{\circ} \mathrm{C}$.

Due to the environment impact of mining and processing of transition metals necessary for inorganic cathodes, organic cathodes have grown in interest in recent years as sustainable alternatives [51]. Perylenetetracarboxylic diimide (PTCDI) is an example of an organic cathode that is a derivative of perylene and has been shown to have the ability to serve as a host for alkali metals $[52,53]$. The cycling study was performed for all three electrolytes at the same current density of $20 \mathrm{~mA} / \mathrm{g}$ of active PTCDI material. All three electrolytes show a gradual rise in the capacity as a function of cycling. We attribute this behavior to the formulation of the cathode slurry. It is possible that the PTCDI molecules interact strongly through $\pi-\pi$ stacking which could limit access to the active carbonyl sites. As subsequent cycles are performed, the intercalation of $\mathrm{Li}^{+}$into the PTCDI could cause a small volume expansion which creates more surface area, resulting in more accessible PTCDI molecules for $\mathrm{Li}^{+}$. Both of the PC and EC-DMC electrolytes show a gradual rise 
and then start to plateau above 70 cycles, attaining a capacity greater than $100 \mathrm{mAh} / \mathrm{g}$. However, beyond 100 cycles, the capacity of the cells starts to fall and is likely due to delamination or dissolution of the active material from extended cycling. Consistent with the other electrode tests the BMIM-TFSI showed the worst performance and low capacity relative to the carbonate electrolytes. Figures S2-S4 show the galvanostatic charging and discharging profiles for each electroactive material in the electrolytes at different cycling rates. Figure S5 shows the full cycling data for the LTO and $\mathrm{TiS}_{2}$ electrodes.

\subsection{FTIR}

To evaluate the solvation of the $\mathrm{Li}^{+}$and $\mathrm{B}_{12} \mathrm{H}_{12}{ }^{-2}$ ions in the different solvents, FTIR was utilized to monitor the changes in the vibrational modes of selected functional groups responsible for the solvation. Figure 6a shows the FTIR of pure PC (black) and the PC$\mathrm{Li}_{2} \mathrm{~B}_{12} \mathrm{H}_{12}$ electrolyte (red) with selected vibrational modes identified. The formation of new vibrational modes is evident in the presence of the salt. The differences are highlighted in the $\Delta$ Transmittance plot (green) in the bottom frame of the figure. The $\Delta$ Transmittance plot is obtained by subtracting the normalized spectrum of pure PC from PC- $\mathrm{Li}_{2} \mathrm{~B}_{12} \mathrm{H}_{12}$ (red spectrum-black spectrum). The negative peaks in this portion of the figure highlight the formation of new peaks formed by the interaction of PC with the dissolved salt. It is known that the shift in the carbonyl resonance $(\mathrm{C}=\mathrm{O})$ to lower wavenumbers and the shift of the carbonate ring structure $\left(\mathrm{O}-\mathrm{CH}_{2}, \mathrm{O}-\mathrm{C}-\mathrm{O}\right.$, and $\left.\mathrm{C}-\mathrm{O}\right)$ to higher wavenumbers is consistent with the solvation of a $\mathrm{Li}^{+}$with $4 \mathrm{PC}$ molecules as previously shown for $\mathrm{LiClO}_{4}$ in $\mathrm{PC}$ [54]. The B-H stretching mode of $\mathrm{Li}_{2} \mathrm{~B}_{12} \mathrm{H}_{12}$ powder (blue) and $\mathrm{PC}-\mathrm{Li}_{2} \mathrm{~B}_{12} \mathrm{H}_{12}$ electrolyte (red) is shown in Figure 6b. A dual peak is shown for the $\mathrm{B}_{12} \mathrm{H}_{12}{ }^{-2}$ due to the unsymmetrical $\mathrm{Li}^{+}$ environment around the cage in the solid state. Upon dissolution in PC, the peak coalesces into one peak and is consistent with a symmetrical solvation environment around the $\mathrm{B}_{12} \mathrm{H}_{12}{ }^{-2}$. Similar behavior has been observed for a $\mathrm{Li}_{2} \mathrm{~B}_{12} \mathrm{H}_{12} \cdot 7 \mathrm{NH}_{3}$ complex in which the $\mathrm{Li}^{+}$are displaced from the $\mathrm{B}_{12} \mathrm{H}_{12}{ }^{-2}$ and solvated by $\mathrm{NH}_{3}$ [55]. It is likely that a similar process is occurring when $\mathrm{Li}_{2} \mathrm{~B}_{12} \mathrm{H}_{12}$ is dissolved in PC. The solvation of the $\mathrm{B}_{12} \mathrm{H}_{12}{ }^{-2}$ is likely achieved by interacting with the electropositive portion of the $\mathrm{PC}$ ring $\left(-\mathrm{CH}_{2}-\right.$ $\left.\mathrm{CH}\left(\mathrm{CH}_{3}\right)-\right)$ rather than the electronegative carbonate portion which favors $\mathrm{Li}^{+}$solvation.

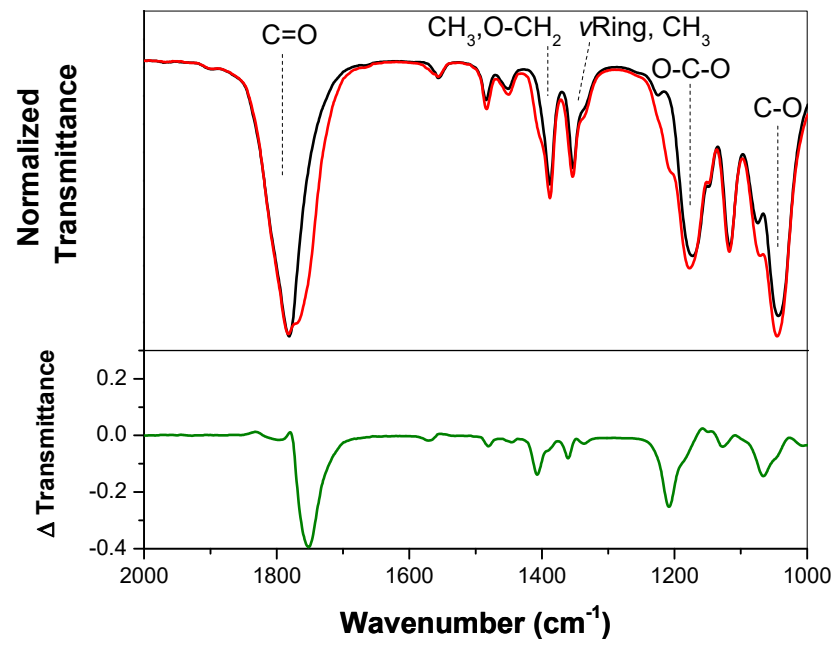

(a)

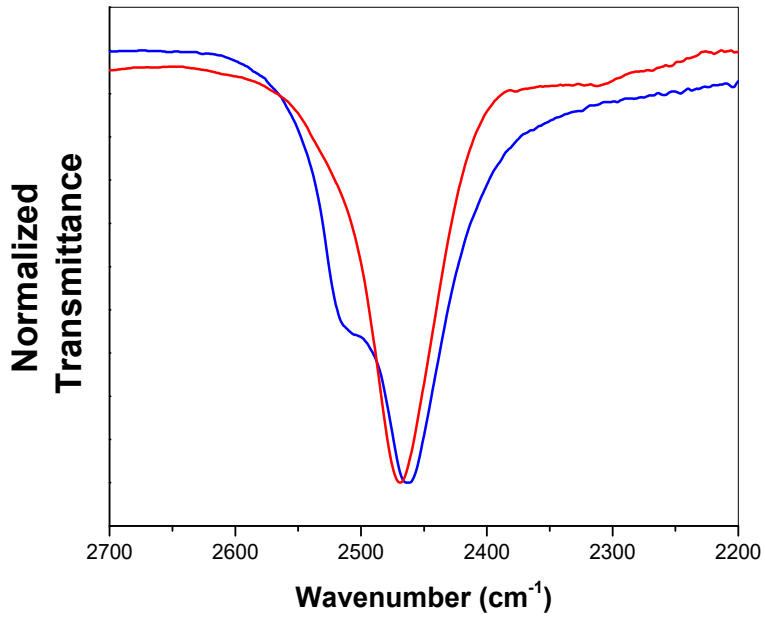

(b)

Figure 6. Selected FTIR regions for PC and the PC- $\mathrm{Li}_{2} \mathrm{~B}_{12} \mathrm{H}_{12}$ electrolyte at $20^{\circ} \mathrm{C}$, (a) PC liquid (black), $\mathrm{PC}$ with $\mathrm{Li}_{2} \mathrm{~B}_{12} \mathrm{H}_{12}$ (red), the difference between the transmittance of the PC solvent with and without the added $\mathrm{Li}_{2} \mathrm{~B}_{12} \mathrm{H}_{12}$ (green). The dashed lines indicate selected modes of PC (b) B-H stretching region of the $\mathrm{B}_{12} \mathrm{H}_{12}{ }^{-2}, \mathrm{Li}_{2} \mathrm{~B}_{12} \mathrm{H}_{12}$ dry powder (blue), (1:1) PC with $\mathrm{Li}_{2} \mathrm{~B}_{12} \mathrm{H}_{12}$ (red). 
Figure 7a shows the FTIR of a pure (1:1) EC-DMC mixture (black) and the EC-DMC $-\mathrm{Li}_{2} \mathrm{~B}_{12} \mathrm{H}_{12}$ electrolyte (red) with the corresponding peaks of the two carbonates labeled. It is clear that the addition of $\mathrm{Li}_{2} \mathrm{~B}_{12} \mathrm{H}_{12}$ interacts with both $\mathrm{EC}$ and DMC based on the changes in peak intensity and formation of new peaks. The $\Delta$ Transmittance plot (green) in the bottom panel highlights the formation of new peaks (negative) and is consistent with EC and DMC facilitating the solvation of $\mathrm{Li}^{+}$as previously shown in a EC-DMC- $\mathrm{LiClO}_{4}$ electrolyte [56]. It is likely that this creates a relatively dynamic solvation environment in this system with multiple energetically similar solvation environments unlike the single component PC solvate. These multiple environments could lead to more disorder in the system and help to create a more mobile $\mathrm{Li}^{+}$, leading to the observed higher ionic conductivity for this electrolyte system. Figure $7 \mathrm{~b}$ shows a result similar to what was observed for $\mathrm{PC}-\mathrm{Li}_{2} \mathrm{~B}_{12} \mathrm{H}_{12}$ in the $\mathrm{B}-\mathrm{H}$ stretching region. The resulting single $\mathrm{B}-\mathrm{H}$ stretch indicates the $\mathrm{B}_{12} \mathrm{H}_{12}{ }^{-2}$ has a symmetrical solvation environment through interaction with the electropositive portion of EC and DMC.

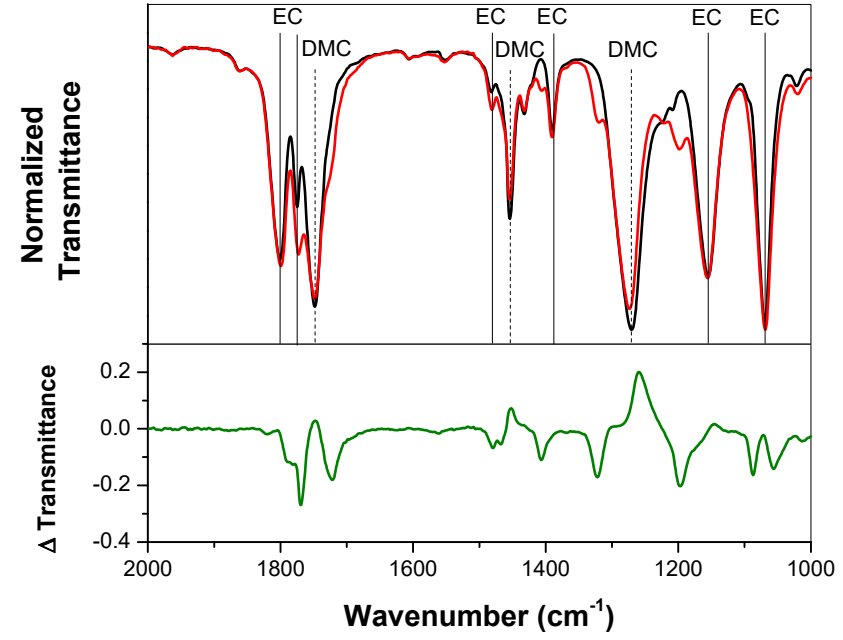

(a)

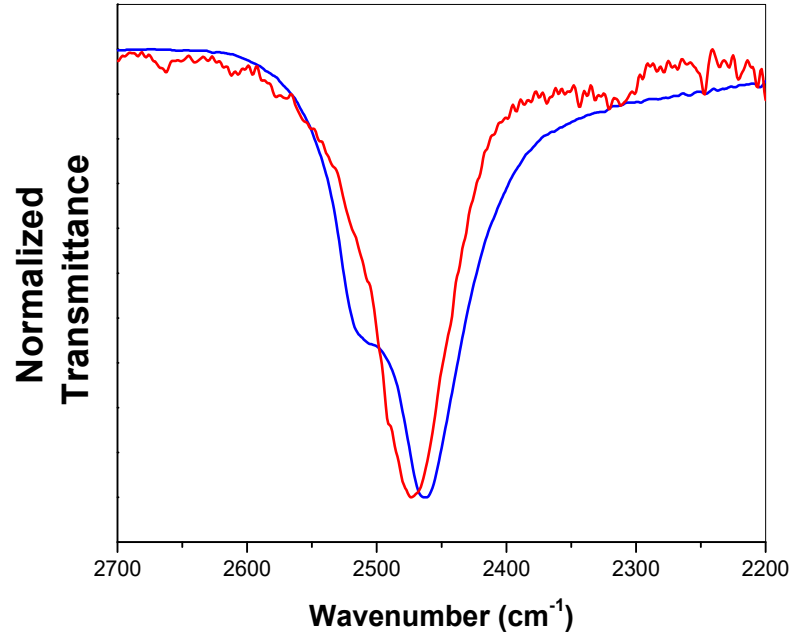

(b)

Figure 7. Selected FTIR regions for EC, DMC, and the EC-DMC- $\mathrm{Li}_{2} \mathrm{~B}_{12} \mathrm{H}_{12}$ electrolyte at $20{ }^{\circ} \mathrm{C}$, (a) (1:1) EC-DMC liquid (black), (1:1) EC-DMC with $\mathrm{Li}_{2} \mathrm{~B}_{12} \mathrm{H}_{12}$ (red), the difference between the transmittance of the EC-DMC solvent with and without the added $\mathrm{Li}_{2} \mathrm{~B}_{12} \mathrm{H}_{12}$ (green), vertical solid and dashed lines indicate vibrations associated with $\mathrm{EC}$ and $\mathrm{DMC}$, respectively; (b) $\mathrm{B}-\mathrm{H}$ stretching region of the $\mathrm{B}_{12} \mathrm{H}_{12}{ }^{-2}, \mathrm{Li}_{2} \mathrm{~B}_{12} \mathrm{H}_{12}$ dry powder (blue), (1:1) EC-DMC with $\mathrm{Li}_{2} \mathrm{~B}_{12} \mathrm{H}_{12}$ (red).

The FTIR of the BMIM-TFSI and BMIM-TFSI- $\mathrm{Li}_{2} \mathrm{~B}_{12} \mathrm{H}_{12}$ liquid electrolyte were also measured in a similar fashion (Figure S6). There are only subtle changes in the relative intensity in the fingerprint region between the IL and the IL- $\mathrm{Li}_{2} \mathrm{~B}_{12} \mathrm{H}_{12}$ electrolyte. Other than the appearance of the B-H stretch centered at $2470 \mathrm{~cm}^{-1}$ due to the added $\mathrm{Li}$ closoborate, there were no obvious new peaks formed as observed for the carbonate-based electrolytes. This is likely due to a much lower affinity for the IL and the $\mathrm{Li}_{2} \mathrm{~B}_{12} \mathrm{H}_{12}$ salt

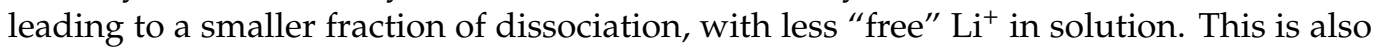
consistent with the lower ionic conductivity and the poor performance in the galvanostatic cycling experiments with the anodes and cathodes tested.

\section{Conclusions}

In this work, we evaluated the effect of three different solvent systems on the electrochemical properties and performance on the $\mathrm{Li}_{2} \mathrm{~B}_{12} \mathrm{H}_{12}$ salt. These studies showed that the EC-DMC had the best overall performance as a solvent for the $\mathrm{Li}_{2} \mathrm{~B}_{12} \mathrm{H}_{12}$ electrolyte salt. Galvanostatic cycling studies showed good stability and capacity retention for LTO, $\mathrm{TiS}_{2}$, and PTCDI up to 300 cycles for the carbonate-based solvents at high charge and discharge rates. The electrolytes showed good stability with Li metal electrodes during 
lithium stripping and plating experiments. This study suggests that the use of a LBRA containing lithium salt in a liquid electrolyte is worthy of further investigation as a halogenfree salt. However, additional fundamental studies are needed to understand solvation environments and dynamics occurring in solution and at the electrode electrolyte interface. Additionally, these materials need to be tested and evaluated with higher voltage cathode materials (i.e., nickel rich NMC) to determine if they are stable and able to work at high current densities. These studies are currently underway and will be reported in due course.

Supplementary Materials: The following are available online at https://www.mdpi.com/article/10 .3390/app12052273/s1, Figure S1: Extended constant current cycling at $1 \mathrm{~mA} / \mathrm{cm}^{2}$, Figure S2: Charge and discharge curves for PC, Figure S3: Charge and discharge curves for EC-DMC, Figure S4: Charge and discharge curves for BMI-TFSI, Figure S5: Full plot of all cycling data for LTO and TiS 2 , Figure S6: FTIR spectrum of the BMIM-TFSI electrolyte.

Author Contributions: M.G., H.S. and K.K. performed the synthesis, electrochemical, and spectroscopic characterization. J.A.T.J. conceived, directed, and oversaw the research. All authors have read and agreed to the published version of the manuscript.

Funding: Initial results were supported by a CSUN Research, Scholarship, and Creative Activity (RSCA) award. The majority of the experiments and results were supported by National Science Foundation Launching Early Academic Pathways in the Mathematical and Physical Sciences (LEAPSMPS) under grant number 2137973.

Institutional Review Board Statement: Not applicable.

Informed Consent Statement: Not applicable.

Data Availability Statement: Data are available upon request to the corresponding author.

Conflicts of Interest: The authors declare no conflict of interest.

\section{References}

1. $\mathrm{Xu}, \mathrm{K}$. Nonaqueous liquid electrolytes for lithium-based rechargeable batteries. Chem. Rev. 2004, 104, 4303-4418. [CrossRef] [PubMed]

2. Watanabe, M.; Thomas, M.L.; Zhang, S.; Ueno, K.; Yasuda, T.; Dokko, K. Application of ionic liquids to energy storage and conversion materials and devices. Chem. Rev. 2017, 117, 7190-7239. [CrossRef] [PubMed]

3. Giri, S.; Behera, S.; Jena, P. Superhalogens as building blocks of halogen-free electrolytes in lithium-ion batteries. Angew. Chem. Int. Ed. 2014, 53, 13916-13919. [CrossRef] [PubMed]

4. Jena, P. Superhalogens: A bridge between complex metal hydrides and Li ion batteries. J. Phys. Chem. Lett. 2015, 6, 1119-1125. [CrossRef]

5. $\quad$ Orimo, S.-I.; Nakamori, Y.; Ohba, N.; Miwa, K.; Aoki, M.; Towata, S.-I.; Züttel, A. Experimental studies on intermediate compound of LiBH4. Appl. Phys. Lett. 2006, 89, 021920. [CrossRef]

6. Hwang, S.-J.; Bowman, R.C.; Reiter, J.W.; Rijssenbeek, J.; Soloveichik, G.L.; Zhao, J.-C.; Kabbour, H.; Ahn, C.C. NMR Confirmation for formation of $\left[\mathrm{B}_{12} \mathrm{H}_{12}\right]^{2-}$ complexes during hydrogen desorption from metal borohydrides. J. Phys. Chem. C 2008, 112, 3164-3169. [CrossRef]

7. Jørgensen, M.; Shea, P.T.; Tomich, A.W.; Varley, J.B.; Bercx, M.; Lovera, S.; Černý, R.; Zhou, W.; Udovic, T.J.; Lavallo, V.; et al. Understanding superionic conductivity in lithium and sodium salts of weakly coordinating closo-hexahalocarbaborate anions. Chem. Mater. 2020, 32, 1475-1487. [CrossRef]

8. Teprovich, J.A.; Colón-Mercado, H.; Washington, A.L., II; Ward, P.A.; Greenway, S.; Missimer, D.M.; Hartman, H.; Velten, J.; Christian, J.H.; Zidan, R. Bi-functional $\mathrm{Li}_{2} \mathrm{~B}_{12} \mathrm{H}_{12}$ for energy storage and conversion applications: Solid-state electrolyte and luminescent down-conversion dye. J. Mater. Chem. A 2015, 3, 22853-22859. [CrossRef]

9. Tang, W.S.; Unemoto, A.; Zhou, W.; Stavila, V.; Matsuo, M.; Wu, H.; Orimo, S.; Udovic, T.J. unparalleled lithium and sodium superionic conduction in solid electrolytes with large monovalent cage-like anions. Energy Environ. Sci. 2015, 8, 3637-3645. [CrossRef]

10. Tang, W.S.; Matsuo, M.; Wu, H.; Stavila, V.; Zhou, W.; Talin, A.A.; Soloninin, A.V.; Skoryunov, R.V.; Babanova, O.A.; Skripov, A.V.; et al. Liquid-like ionic conduction in solid lithium and sodium monocarba-closo-decaborates near or at room temperature. Adv. Energy Mater. 2016, 6, 1502237. [CrossRef]

11. Udovic, T.J.; Matsuo, M.; Unemoto, A.; Verdal, N.; Stavila, V.; Skripov, A.V.; Rush, J.J.; Takamura, H.; Orimo, S. Sodium superionic conduction in $\mathrm{Na}_{2} \mathrm{~B}_{12} \mathrm{H}_{12}$. Chem. Commun. 2015, 50, 3750-3752. [CrossRef] [PubMed] 
12. Udovic, T.J.; Matsuo, M.; Tang, W.S.; Wu, H.; Stavila, V.; Soloninin, A.V.; Skoryunov, R.V.; Babanova, O.A.; Skripov, A.V.; Rush, J.J.; et al. Exceptional superionic conductivity in disordered sodium decahydro-closo-decaborate. Adv. Mater. 2014, 26, 7622-7626. [CrossRef] [PubMed]

13. Dimitrievska, M.; Shea, P.; Kweon, K.E.; Bercx, M.; Varley, J.B.; Tang, W.S.; Skripov, A.V.; Stavila, V.; Udovic, T.J.; Wood, B.C. Carbon incorporation and anion dynamics as synergistic drivers for ultrafast diffusion in superionic $\mathrm{LiCB}_{11} \mathrm{H}_{12}$ and $\mathrm{NaCB}_{11} \mathrm{H}_{12}$. Adv. Energy Mater. 2018, 8, 1703422. [CrossRef]

14. Duchêne, L.; Lunghammer, S.; Burankova, T.; Liao, W.-C.; Embs, J.P.; Copéret, C.; Wilkening, H.M.R.; Remhof, A.; Hagemann, H.; Battaglia, $\mathrm{C}$. Ionic conduction mechanism in the $\mathrm{Na}_{2}\left(\mathrm{~B}_{12} \mathrm{H}_{12}\right)_{0.5}\left(\mathrm{~B}_{10} \mathrm{H}_{10}\right)_{0.5}$ closo-borate solid-state electrolyte: Interplay of disorder and ion-ion interactions. Chem. Mater. 2019, 31, 3449-3460. [CrossRef]

15. Asakura, R.; Reber, D.; Duchêne, L.; Payandeh, S.; Remhof, A.; Hagemann, H.; Battaglia, C. 4 V room-temperature all-solid-state sodium battery enabled by a passivating cathode/hydroborate solid electrolyte interface. Energy Environ. Sci. 2020, 13, 5048-5058. [CrossRef]

16. Tang, W.S.; Matsuo, M.; Wu, H.; Stavila, V.; Unemoto, A.; Orimo, S.; Udovic, T.J. Stabilizing lithium and sodium fast-ion conduction in solid polyhedral-borate salts at device-relevant temperatures. Energy Storage Mater. 2016, 4, 79-83. [CrossRef]

17. He, L.; Li, H.-W.; Nakajima, H.; Tumanov, N.; Filinchuk, Y.; Hwang, S.-J.; Sharma, M.; Hagemann, H.; Akiba, E. Synthesis of a bimetallic dodecaborate LiNaB12H12 with outstanding superionic conductivity. Chem. Mater. 2015, 27, 5483-5486. [CrossRef]

18. Duchêne, L.; Kühnel, R.-S.; Rentsch, D.; Remhof, A.; Hagemann, H.; Battaglia, C. A highly stable sodium solid-state electrolyte based on a dodeca/deca-borate equimolar mixture. Chem. Commun. 2017, 53, 4195-4198. [CrossRef]

19. Sadikin, Y.; Brighi, M.; Schouwink, P.; Černý, R. Superionic conduction of sodium and lithium in anion-mixed hydroborates $\mathrm{Na}_{3} \mathrm{BH}_{4} \mathrm{~B}_{12} \mathrm{H}_{12}$ and $\left(\mathrm{Li}_{0.7} \mathrm{Na}_{0.3}\right)_{3} \mathrm{BH}_{4} \mathrm{~B}_{12} \mathrm{H}_{12}$. Adv. Energy Mater. 2015, 5, 1501016. [CrossRef]

20. Payandeh, S.; Asakura, R.; Avramidou, P.; Rentsch, D.; Łodziana, Z.; Černý, R.; Remhof, A.; Battaglia, C. Nido-borate/closo-borate mixed-anion electrolytes for all-solid-state batteries. Chem. Mater. 2020, 32, 1101-1110. [CrossRef]

21. Teprovich, J.A.; Colón-Mercado, H.R.; Ward, P.A.; Peters, B.; Giri, S.; Zhou, J.; Greenway, S.; Compton, R.N.; Jena, P.; Zidan, R. Experimental and theoretical analysis of fast lithium ionic conduction in a $\mathrm{LiBH}_{4}-\mathrm{C}_{60}$ nanocomposite. J. Phys. Chem. C 2014, 118, 21755-21761. [CrossRef]

22. Santos, J.A.; Simon, P.; Bernot, A.R.; Babasi, C.; Ward, P.A.; Hwang, S.-J.; Zidan, R.; Teprovich, J.A. Synergistic effect of nanoionic destabilization and partial dehydrogenation for enhanced ionic conductivity in $\mathrm{MBH}_{4}-\mathrm{C}_{60}\left(\mathrm{M}=\mathrm{Li}^{+}, \mathrm{Na}^{+}\right)$nanocomposites. $J$. Solid State Electrochem. 2021, 25, 1441-1452. [CrossRef]

23. Shane, D.T.; Corey, R.L.; Rayhel, L.H.; Wellons, M.; Teprovich, J.A.; Zidan, R.; Hwang, S.-J.; Bowman, R.C.; Conradi, M.S. NMR study of $\mathrm{LiBH}_{4}$ with $\mathrm{C}_{60}$. J. Phys. Chem. C 2010, 114, 19862-19866. [CrossRef]

24. Verdal, N.; Udovic, T.J.; Stavila, V.; Tang, W.S.; Rush, J.J.; Skripov, A.V. Anion reorientations in the superionic conducting phase of $\mathrm{Na}_{2} \mathrm{~B}_{12} \mathrm{H}_{12}$. J. Phys. Chem. C 2014, 118, 17483-17489. [CrossRef]

25. Skripov, A.V.; Babanova, O.A.; Soloninin, A.V.; Stavila, V.; Verdal, N.; Udovic, T.J.; Rush, J.J. Nuclear magnetic resonance study of atomic motion in $\mathrm{A}_{2} \mathrm{~B}_{12} \mathrm{H}_{12}(\mathrm{~A}=\mathrm{Na}, \mathrm{K}, \mathrm{Rb}, \mathrm{Cs})$ : Anion reorientations and $\mathrm{Na}^{+}$mobility. J. Phys. Chem. C 2013, 117, 25961-25968. [CrossRef]

26. Verdal, N.; Her, J.-H.; Stavila, V.; Soloninin, A.V.; Babanova, O.A.; Skripov, A.V.; Udovic, T.J.; Rush, J.J. Complex high-temperature phase transitions in $\mathrm{Li}_{2} \mathrm{~B}_{12} \mathrm{H}_{12}$ and $\mathrm{Na}_{2} \mathrm{~B}_{12} \mathrm{H}_{12}$. J. Solid State Chem. 2014, 212, 81-91. [CrossRef]

27. Soloninin, A.V.; Dimitrievska, M.; Skoryunov, R.V.; Babanova, O.A.; Skripov, A.V.; Tang, W.S.; Stavila, V.; Orimo, S.-I.; Udovic, T.J. Comparison of anion reorientational dynamics in $\mathrm{MCB}_{9} \mathrm{H}_{10}$ and $\mathrm{M}_{2} \mathrm{~B}_{10} \mathrm{H}_{10}(\mathrm{M}=\mathrm{Li}, \mathrm{Na})$ via nuclear magnetic resonance and quasielastic neutron scattering studies. J. Phys. Chem. C 2017, 121, 1000-1012. [CrossRef]

28. Sau, K.; Ikeshoji, T.; Kim, S.; Takagi, S.; Orimo, S.-I. Comparative molecular dynamics study of the roles of anion-cation and cation-cation correlation in cation diffusion in $\mathrm{Li}_{2} \mathrm{~B}_{12} \mathrm{H}_{12}$ and $\mathrm{LiCB}_{11} \mathrm{H}_{12}$. Chem. Mater. 2021, 33, 2357-2369. [CrossRef]

29. Kweon, K.E.; Varley, J.B.; Shea, P.; Adelstein, N.; Mehta, P.; Heo, T.W.; Udovic, T.J.; Stavila, V.; Wood, B.C. Structural, chemical, and dynamical frustration: Origins of superionic conductivity in closo-borate solid electrolytes. Chem. Mater. 2017, 32, 9142-9153. [CrossRef]

30. Varley, J.B.; Kweon, K.; Mehta, P.; Shea, P.; Heo, T.W.; Udovic, T.J.; Stavila, V.; Wood, B.C. Understanding ionic conductivity trends in polyborane solid electrolytes from ab initio molecular dynamics. ACS Energy Lett. 2017, 2, 250-255. [CrossRef]

31. Tang, W.S.; Yoshida, K.; Soloninin, A.V.; Skoryunov, R.V.; Babanova, O.A.; Skripov, A.V.; Dimitrievska, M.; Stavila, V.; Orimo, S.-I.; Udovic, T.J. Stabilizing superionic-conducting structures via mixed-anion solid solutions of monocarba-closo-borate salts. ACS Energy Lett. 2016, 1, 659-664. [CrossRef]

32. Li, S.; Qiu, P.; Kang, J.; Ma, Y.; Zhang, Y.; Yan, Y.; Jensen, T.R.; Guo, Y.; Zhang, J.; Chen, X. Iodine-substituted lithium/sodium closodecaborates: Syntheses, characterization, and solid-state ionic conductivity. ACS Appl. Mater. Interfaces 2021, 13, 17554-17564. [CrossRef] [PubMed]

33. Dimitrievska, M.; Wu, H.; Stavila, V.; Babanova, O.A.; Skoryunov, R.V.; Soloninin, A.V.; Zhou, W.; Trump, B.A.; Andersson, M.S.; Skripov, A.V.; et al. Structural and dynamical properties of potassium dodecahydro-monocarba-closo-dodecaborate: $\mathrm{KCB}_{11} \mathrm{H}_{12} \cdot J_{\text {. }}$ Phys. Chem. C 2020, 124, 17992-18002. [CrossRef]

34. Johnson, J.W.; Whittingham, M.S. Lithium closoboranes as electrolytes in solid cathode lithium cells. J. Electrochem. Soc. 1980, 127, 1653-1654. [CrossRef] 
35. Johnson, J.W.; Thompson, A.H. Lithium closoboranes II. Stable nonaqueous electrolytes for elevated temperature lithium cells. J. Electrochem. Soc. 1981, 128, 932-933. [CrossRef]

36. Johnson, J.W.; Brody, J.F. Lithium closoborane electrolytes: III. Preparation and characterization. J. Electrochem. Soc. 1982, 129, 2213-2219. [CrossRef]

37. Chen, Z.; Ren, Y.; Jansen, A.N.; Lin, C.-K.; Weng, W.; Amine, K. New class of nonaqueous electrolytes for long-life and safe lithium-ion batteries. Nat. Commun. 2013, 4, 1513. [CrossRef]

38. Ionica-Bousquet, C.M.; Muñoz-Rojas, D.; Casteel, W.J.; Pearlstein, R.M.; GirishKumar, G.; Pez, G.P.; Palacín, M.R. Polyfluorinated boron cluster-based salts: A new electrolyte for application in $\mathrm{Li}_{4} \mathrm{Ti}_{5} \mathrm{O}_{12} / \mathrm{LiMn}_{2} \mathrm{O}_{4}$ rechargeable lithium-ion batteries. J. Power Sources 2010, 195, 1479-1485. [CrossRef]

39. Hayamizu, K.; Matsuo, A.; Arai, J. A divalent lithium salt $\mathrm{Li}_{2} \mathrm{~B}_{12} \mathrm{~F}_{12}$ dissolved in propylene carbonate studied by NMR methods. J. Electrochem. Soc. 2009, 156, A744-A750. [CrossRef]

40. Arai, J.; Matsuo, A.; Fujisaki, T.; Ozawa, K. A novel high temperature stable lithium salt $\left(\mathrm{Li}_{2} \mathrm{~B}_{12} \mathrm{~F}_{12}\right)$ for lithium ion batteries. $J$. Power Sources 2009, 193, 851-854. [CrossRef]

41. He, L.; Li, H.-W.; Hwang, S.-J.; Akiba, E. Facile solvent-free synthesis of anhydrous alkali metal dodecaborate $\mathrm{M}_{2} \mathrm{~B}_{12} \mathrm{H}_{12}(\mathrm{M}=\mathrm{Li}$, Na, K). J. Phys. Chem. C 2014, 118, 6084-6089. [CrossRef]

42. Green, M.; Kaydanik, K.; Orozco, M.; Hanna, L.; Marple, M.A.T.; Fessler, K.A.S.; Jones, W.B.; Stavila, V.; Ward, P.A.; Teprovich, J.A.T., Jr. Closo-borate gel polymer electrolyte with remarkable electrochemical stability and a wide operating temperature window. Adv. Sci. 2022; revised manuscript submitted.

43. Kim, S.; Oguchi, H.; Toyama, N.; Sato, T.; Takagi, S.; Otomo, T.; Arunkumar, D.; Kuwata, N.; Kawamura, J.; Orimo, S.-I. A complex hydride lithium superionic conductor for high-energy-density all-solid-state lithium metal batteries. Nat. Commun. 2019, $10,1081$. [CrossRef] [PubMed]

44. Pfaffenhuber, C.; Göbel, M.; Popovic, J.; Maier, J. Soggy-sand electrolytes: Status and perspectives. Phys. Chem. Chem. Phys. 2013, 15, 18318-18335. [CrossRef] [PubMed]

45. Jarosik, A.; Pfaffenhuber, C.; Bunde, A.; Maier, J. Electrochemical investigations of polyethylene glycol-based "soggy sand" electrolytes-From the local mechanism to the overall conduction. Adv. Funct. Mater. 2011, 21, 3961-3966. [CrossRef]

46. Kumar, B.; Rodrigues, S.J. Ionic conductivity of colloidal electrolytes. Solid State Ion. 2004, 167, 91-97. [CrossRef]

47. Hall, D.S.; Self, J.; Dahn, J.R. Dielectric constants for quantum chemistry and Li-ion batteries: Solvent blends of ethylene carbonate and ethyl methyl carbonate. J. Phys. Chem. C 2015, 119, 22322-22330. [CrossRef]

48. Huang, M.-M.; Jiang, Y.; Sasisanker, P.; Driver, G.W.; Weingärtner, H. Static relative dielectric permittivities of ionic liquids at $25^{\circ}$ C. J. Chem. Eng. Data 2011, 56, 1494-1499. [CrossRef]

49. Krauskopf, T.; Richter, F.H.; Zeier, W.G.; Janek, J. Physicochemical concepts of the lithium metal anode in solid-state batteries. Chem. Rev. 2020, 120, 7745-7794. [CrossRef]

50. Wood, K.N.; Kazyak, E.; Chadwick, A.F.; Chen, K.-H.; Zhang, J.-G.; Thornton, K.; Dasgupta, N.P. Dendrites and pits: Untangling the complex behavior of lithium metal anodes through operando video microscopy. ACS Cent. Sci. 2016, 2, 790-801. [CrossRef]

51. Lyu, H.; Sun, X.-G.; Dai, S. Organic cathode materials for lithium-ion batteries: Past, present, and future. Adv. Energy Sustain. Res. 2021, 2, 2000044. [CrossRef]

52. Deng, W.; Shen, Y.; Qian, J.; Cao, Y.; Yang, H. A perylene diimide crystal with high capacity and stable cyclability for Na-ion batteries. ACS Appl. Mater. Interfaces 2015, 7, 21095-21099. [CrossRef] [PubMed]

53. Xiong, M.; Tang, W.; Cao, B.; Yang, C.; Fan, C. A small-molecule organic cathode with fast charge-discharge capability for K-ion batteries. J. Mater. Chem. A 2019, 7, 20127-20131. [CrossRef]

54. Ikezawa, Y.; Ariga, T. In situ FTIR spectra at the Cu electrode/propylene carbonate solution interface. Electrochim. Acta 2007, 52, 2710-2715. [CrossRef]

55. Huang, Z.; Gallucci, J.; Chen, X.; Yisgedu, T.; Lingam, H.K.; Shore, S.G.; Zhao, J.-C. $\mathrm{Li}_{2} \mathrm{~B}_{12} \mathrm{H}_{12} \cdot 7 \mathrm{NH}_{3}$ : A new ammine complex for ammonia storage or indirect hydrogen storage. J. Mater. Chem. 2010, 20, 2743-2745. [CrossRef]

56. Ikezawa, Y.; Nishi, H. In situ FTIR study of the Cu electrode/ethylene carbonate+dimethyl carbonate solution interface. Electrochim. Acta 2008, 53, 3663-3669. [CrossRef] 